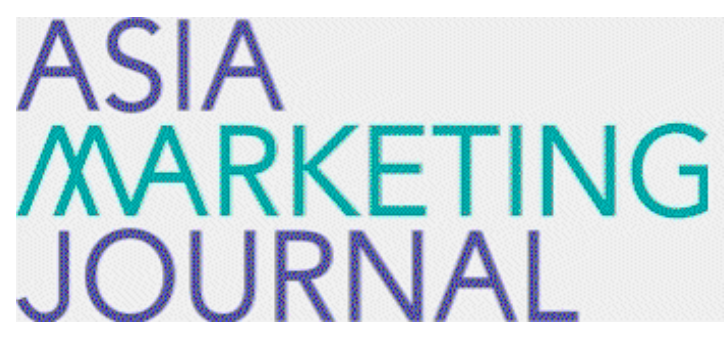

ASIA MARKETING JOURNAL

Volume 22 | Issue 2

Article 3

$7-31-2020$

\title{
The Role of Imagery vs. Analytical Advertisement on New \\ Products Evaluation
}

Juyon Lee

Wujin Chu

Follow this and additional works at: https://amj.kma.re.kr/journal

Part of the Marketing Commons

\section{Recommended Citation}

Lee, Juyon and Chu, Wujin (2020) "The Role of Imagery vs. Analytical Advertisement on New Products Evaluation," Asia Marketing Journal: Vol. 22 : Iss. 2 , Article 3.

Available at: https://doi.org/10.15830/amj.2020.22.2.59

This Article is brought to you for free and open access by Asia Marketing Journal. It has been accepted for inclusion in Asia Marketing Journal by an authorized editor of Asia Marketing Journal. 


\title{
The Role of Imagery vs. Analytical Advertisement on New Products Evaluation*
}

\author{
Juyon Lee** \\ Wujin $\mathrm{Chu}^{* * *}$
}

Combining prior theories on innovation newness with information processing style (imagery vs. analytical), this study presents a theoretical framework; develops hypotheses; and makes predictions on how analytical versus imagery ads influence consumers differently depending on the newness level of products. The study shows that consumers are more likely to evaluate RNPs (radicallyinnovative new products) positively when they are advertised with imagery cues. Compared with analytical advertisements, imagery advertisements increased advertising effectiveness, product evaluation, and purchase intention of RNPs. These effects were demonstrated by using stimuli from two product categories consisting of washing machines and cars.

In particular, in advertisement for RNPs, verbal description that induced imagery processing, such as "picture yourself using this product," was more effective in generating favorable responses, compared to verbal description that induced analytical processing, such as explanation of product attributes. This difference was present for RNPs, but not for INPs (incrementally-innovative new products).

INPs are continuous innovations that are easier to understand, thus imagery ads do not provide additional advantage for consumers in understanding the innovation, compared to analytical ads. In RNPs, imagery ads can highlight new benefits that may have been neglected or undervalued by consumers, leading to greater message persuasiveness. Implications for marketing of RNPs are discussed.

Keywords: innovation newness, imagery vs. analytical advertisement, attitude toward ad, product evaluations, purchase intention, message persuasiveness

This paper has received financial support from Marketing Research Center, Seoul National University.

** Ph.D. Student of Marketing, Graduate School of Business Administration, Seoul National University (juyon21@snu.ac.kr)

*** Professor of Marketing, College of Business Administration, Seoul National University (wchu@snu.ac.kr),

Corresponding Author 


\section{Introduction}

Imagine that you are the product manager of the recently launched washing machine, a new product that provides benefits of doing eco-friendly laundry without using water or detergent. Considering the most effective way to communicate the benefits of this really innovative washing machine, you decided to make an advertisement. Through the advertisement message, you may provide consumers with detailed information of new product attribute by attribute, or you may encourage consumers to imagine and visualize themselves using this new product. Does providing analytical or imagery advertisement work as an effective communication strategy to enhance consumers' adoption of a really innovative new product? Is there any possibility that different information processing (imagery vs. analytical) may generate different effects on consumers depending on innovation newness? And do consumers process advertisement for RNPs(radically new products) versus INPS(incrementally innovative new products) in a different manner?

In this article, we examine how different presentations of advertising information impacts consumers' new product evaluations. We suggest that the effectiveness of this cognitive approach depends on the innovation newness level of products. Previous research has demonstrated that certain dimensions of consumer responses to advertisements and other marketing stimuli can vary with the perceived "innovation newness level" of the product (Hoeffler 2003; Zhao, Hoeffler, and Dahl 2009; Ma, Gill, and Jiang 2015). For example, prior research found differences in information search behavior depending on the level of discrepancy from preexisting product category expectations (Dahl and Hoeffler 2014; Oliver, Robertson, and Mitchell 1993; Zhao, Dahl, and Hoeffler 2014; Zhao, Hoeffler, and Dahl 2009; Zhao, Hoeffler, and Dahl 2012).

The use of mental imagery is a widespread practice to help consumers understand the benefits associated with new products (Escalas 2004). Imagery also reduces consumer's uncertainty of achieving those new benefits of innovative products (Feiereisen, Wong, and Broderick 2008; Zhao, Hoeffler, and Dahl 2012). Indeed, consumers are often asked to imagine their consumption experiences through advertisements. Television, radio, and print advertisements include phrases such as "imagine yourself," and "picture how it would be," and elicit imagery processing in consumers. Imagery processing or "imagery" is a form of cognitive processing in which visual information is represented in working memory (MacInnis and Price 1987), and it has been distinguished from the more data-driven analytical processing (Escalas 2004; Petrova and Cialdini 2005; Roy and Phau 2014; Thompson and Hamilton 2006). Imagery versus analytical processing has been manipulated 
by intrinsic message cues such as narrative and descriptive words rather than data-driven information (Bolls and Muehling 2007; Keller and Block 1997; Roy and Phau 2014; Thompson and Hamilton 2006).

In addition to message characteristics, imagery has also been shown to be moderated by variables such as instructions to imagine, individual differences, and situational context (Escalas 2004; Petrova and Cialdini 2005; Roy and Phau 2014; Thompson and Hamilton 2006: Wyer, Hung, and Jiang 2008). However, given that consumers are exposed to numerous new products and advertisements of these new products in their everyday lives, the role of innovation newness level in information processing is under researched. Current literature posits that matching a specific type of information (e.g., imagery, analytical, abstract, concrete) with the innovation newness level (i.e., RNI (really new innovation) vs. INI (incrementally new innovation)) can lead to differences in ad effectiveness, positive product evaluation, and higher purchase intention.

Research evidence shows that different levels of innovation newness leads to different construal level and effect information choice in consumer decisions (Castano, Sujan, Kacker, and Sujan 2008; Zhao, Dahl, and Hoeffler 2014). For example, a radically new innovation (RNI) is associated with high-level construal and benefit-focused product information, while incrementally new innovation (INI) is associated with low-level construal, attribute-focused product information (Alexander, Lynch, and Wang 2008; Lee and Chu 2020).

Prior research reports that radically new products can be better understood while activating one's imagination (Zhao, Hoeffler, and Dahl 2009; Zhao, Hoeffler, and Dahl 2012). Despite this linkage, few research has explored whether imagery (versus analytical) advertisement can influence the evaluation of RNPS. In this research, we seek to examine how the advertisement type impacts the evaluation of RNPs in comparison with INPs. We show that by the degree of innovation newness of the product, certain type of advertisement can enhance ad effectiveness, product evaluation, and purchase intention more than others type of advertisement.

In the next section, we provide the relevant theoretical background on imagery versus analytical ad, innovation newness, and predicted interaction effect underlying the research hypotheses. Then we present two studies to test whether the imagery (vs. analytical) ads enhances ad effectiveness, product evaluation, and purchase intention of the RNPs (vs. INPS). We conclude with a discussion of our results, their implications, and suggestions for future research. 


\section{Theoretical Background and Hypotheses Development}

\subsection{Advertisement Type: Imagery vs. Analytical Ads}

Imagery is a holistic, sensory method of encoding, processing, retrieving information that is an important focus of consumer research (Bone and Ellen 1992; Petrova and Cialdini 2005). Imagery is a multidimensional cognitive construct that represents some type of sensory experience in working memory (MacInnis and Price 1987; Petrova and Cialdini 2005). Also, evocation of imagery is often a multi-sensory experience (Roy and Phau 2014). Imagery processing is a sensory representation of information in memory, as opposed to reason-based processing (Childers, Houston, and Heckler 1985). Also the effect of imagery on product preference remains significant even after controlling for affect (Escalas 2004; Mani and MacInnis 2001). Imagery processing has been studied in various marketing contexts, including advertising effectiveness (Edell and Stalin 1983; Thompson and Hamilton 2006), attitude development (Kiselius and Sternthal 1984), preference formation (Petrova and Cialdini 2005), creativity in product design (Dahl, Chattopadhyay, and Gorn 1999), and anticipatory satisfaction of consumption experience (MacInnis and Price 1987, 1990; Shiv and
Huber 2000). Further, imagery is widely operationalized by advertisers in detailed forms such as color, symbols, and drama (Burke and Edell 1989; Oliver, Robertson, and Mitchell 1993).

By contrast, analytical processing is data driven and focuses on verbal encoding and retrieval, rather than sensory experiences (MacInnis and Price 1987; Roy and Phau 2014; Thompson and Hamilton 2006). In analytical mode, products are evaluated on attribute-by-attribute basis, and the decision maker combines relevant attribute information to form an overall attitude towards the product (Sujan 1985: Roy and Phau 2014; Thompson and Hamilton 2006). In other words, analytical processing leads the evaluator to focus on the attributes of the brand, rather than view the brand itself holistically (MacInnis and Price 1987; Roy and Phau 2014; Thompson and Hamilton 2006). In this sense, analytical processing is closer to the rational model of consumer utility maximization.

It is important to distinguish between imagery and analytical processing modes. Characteristics of message attributes induce either imagery or analytical processing styles. Imagery can be manipulated in various ways such as the presence or absence of pictures (Kisielius and Sternthal 1986), instructions to imagine (Petrova and Cialdini 2005), and the provision of narrative or quantitative information (Keller and Block 1997). Also imagery and analytical processing mode are different processing styles that are 
related but conceptually distinctive constructs (Roy and Phau 2014) such as "abstract versus concrete" or "bottom-up versus top-down" processing modes (Gasper 2004; Smith and Trope 2006). In Thompson and Hamilton (2006) and Roy and Phau (2014), descriptor sentences were used to manipulate an imagery advertisement, while a matrix (attribute by attribute) information was used to manipulate analytical advertisement.

\subsection{Innovation Newness Level: INPs vs. RNPS}

For successful management of new products, it is very important to identify the main factors that influence consumers' adoption intention (Hauser, Tellis, and Griffin 2006). Researchers have found that factors such as innovation newness, compatibility, future richness, network externality, familiarity, and perceived risk can influence consumer adoption of innovation (Hoeffler 2003; Lee and Chu 2020; Ma, Gill, and Jiang 2015; Ostlund 1974; Rogers 2003).

Since the level of innovation newness is an important factor in the adoption of innovation, researchers have distinguished RNIs (really new innovations) and INIs (incrementally new innovations) (Hoeffler 2003). RNIs are characterized by discontinuities in terms of technology or the market (Gracia and Calatone 2002), while INIs are characterized by an improvement of existing products. RNIs offer radically new benefits not available from existing products, whereas INIs offer incrementally new benefits (Hoeffler 2003; Ma, Gill, and Jiang 2015). Thus, RNIs are often inconsistent with existing products, which may lead to consumer resistance (Jhang, Grant, and Campbell 2012; Ma, Gill, and Jiang 2015). A central focus of our study is whether the information processing in an imagery versus analytic advertisement affects adoption intentions for RNIs versus INIs, or equivalently RNPs (radically innovative new products) versus INPS (incrementally innovative new products). RNPs create greater uncertainty to consumers than INPs do. Consumers attempt to minimize this uncertainty through inferential processes. However, most market research methods are appropriate for INPs since only consumers who have prior knowledge relevant to the product or product category can evaluate accurately the importance of new benefits of the product concept being tested. Consumers have a very limited knowledge about RNPs due to their radically innovative nature. Thus, consumers must construct preferences for RNPs at the time of measurement (Hoeffler 2003). Research in decision making suggest that when preferences are constructed at the time of measurement, rather than retrieved from something the consumer knows already, the information processing procedure is unstable and context dependent (Fischhoff 1991; Payne, Bettman, and Johnson 1992; Slovic 1995). Consumers 
perceive greater uncertainty when predicting or estimating the benefits of RNPs, because for RNPs, there is little information to be retrieved from memory (Hoeffler 2003).

\subsection{The Role of Ad Type on the Evaluation of New Products}

While the literature has shown imagery processing plays an important role in product evaluation, few research has been conducted toward the innovation newness. The central focus of this research is to assess the impact of imagery vs. analytical ads on the evaluation of RNPs. However, without comparison to INPs, we would not be able to qualify innovation newness level as an important moderator for the positive impact of imagery advertisement on new product evaluation and purchase intention (Zhao, Hoeffler, and Dahl 2009).

How will innovation newness moderate the effect of imagery vs. analytical ads on the evaluation of RNPs and INPs? Compared with INPs that build on established products and allow consumers to draw prior experiences, RNPs represent entirely new product categories and enable consumers to do something they have never been able to do before (Lehman 1997). For RNPs, consumers have low product knowledge and are often uncertain about the consumption utility associated with new benefits (Hoeffler 2003).

When introducing a new product, it must be first decided how to describe the product to the potential buyer (Ma, Gill, and Jiang 2015). It is relatively easy to describe INPs because consumers usually possess prior knowledge and experience in the same domain to understand what the new product is. Thus, for INPs, simple identification of the category may suffice. However, more learning is required to understand the novel benefits of RNPs (Hoeffler 2003; Ma, Gill, and Jiang 2015).

For RNPs, consumers are more dependent on contexts and tend to use contextual factors as diagnostic cues (Hoeffler 2003). Usefulness of category knowledge is limited in evaluating RNPs (Lehman 1997). While category knowledge is better suited for organizing existing information, analogy is better for processing entirely new information (Gregan-Paxton and John 1997). Since RNPs purport to provide benefits that have never been offered before, imagery, rather than attribute rating, is suitable for constructing a product-usage scenario, in aiding the evaluation of the new offering (Smith, Mitchell, and Meyer 1982; Oliver, Robertson, and Mitchell 1993). Thus, as innovations move from continuous to discontinuous, the need for imagery may increase. Imagery processing of RNPs enhances understanding of novel benefits that were neglected in the existing product category, leading to higher product evaluation (Zhao, Hoeffler, and Dahl 2009).

Human beings are inclined to conserve cognitive resources whenever possible, and 
would often take shortcuts by relying on the most easily accessible information for decisions (Bettman, Luce, and Payne 1998). For INPs, consumers having baseline knowledge of the product in the existing category is more likely to utilize this knowledge in product evaluation. Understanding INPs is not cognitively effortful (Zhao, Hoeffler, and Dahl 2009). However, for RNPs, there is a need to link the new product to novel consumer goals, in the form of the consequences of product use. For such persuasion, the use of imagery would facilitate the benefits of RNPs more effectively (Oliver, Robertson, and Mitchell 1993).

Because RNPs provide new and unfamiliar benefits, additional learning is required of the consumer (Hoeffler 2003; Mukherjee and Hoyer 2001). Imagery processing can aid the learning process. However, for INPs consumers can understand and evaluate the benefits easily by using their existing framework for evaluation (Mukerjee and Hoyer 2001). Thus, in case of INPs, it is less likely that imagery processing will produce different outcomes from analytical processing. We posit that the effect of ad type (imagery vs. analytical) on consumers' product evaluation and purchase intention will differ for RNPs and INPs. We demonstrate that RNPs are evaluated positively when they are advertised with imagery information. Relative to analytical ads, imagery ads are more effective when consumers evaluate RNPs. When imagery ad is used for RNPs, the message is perceived as more persuasive and ultimately lead to higher purchase intentions. By contrast, for INPs, the imagery ad does not make a differential impact on the evaluation of INPs over analytical ad.

On the basis of the foregoing discussion, we propose the following hypotheses:

H1: Imagery (vs. analytical) advertisement increases the positive attitude toward advertisement of RNPS, however, the type of advertisements does not make differential impact on the attitude toward advertisement of INPS.

H2: Imagery (vs. analytical) advertisement increases the positive evaluation of RNPS, whereas there is no difference between the two types of advertisements on the evaluation of INPS.

H3: Imagery (vs. analytical) advertisement increases the purchase intention of RNPS, but it has no differential impact on the purchase intention of INPS.

H4: Imagery (vs. analytical) advertisement increases the message persuasiveness of $R N P S$, whereas there is no differential impact of advertisement type on the message persuasiveness of INPS. 


\section{Methods and Analysis}

In order to manipulate the innovation newness level, it is necessary to choose a stimulus that can be recognized so that the innovation newness level is statistically significant. Hightech products are suitable for this. Washing machines and automobiles are easy to evaluate because they are familiar products that consumers encounter every day. Through the cross-category (washing machine, automobile) analysis, the robustness of the experimental results is enhanced and the theory is generalized. Thus, we used a washing machine in Experiment 1 and a car in Experiment 2 as stimuli.

\section{Study 1. Washing Machine}

\subsection{Pretest for product stimuli}

\subsubsection{Pretest 1. Visual Description (Picture) of Stimuli}

Ninety seven participants from online survey company responded to this survey. Following current literature (Ma, Gill, and Jiang 2015; Noseworthy, Cotte, and Lee 2011), pretest was conducted using three pictures of washing machines, which varied in accordance with the innovation newness level (e.g., shape and metric properties). Participants were shown one of the washing machines and then responded to a questionnaire.

Perceived innovation newness was measured by three 9-point items (not at all new/extremely new, not at all novel/extremely novel, not at all innovative/extremely innovative; $\alpha=$ .894: Ma, Gill, and Jiang 2015). The One-Way ANOVA ( $\mathrm{n}=97)$ results confirmed that operation of visual description (picture) of innovation newness was successful $(F(2)=29.346, p<$ $.001)$. Please refer to appendix for the pretest results.

\subsubsection{Pretest 2. Visual (Picture) and Verbal (Message) Description of Stimuli}

One hundred and forty (55.7\% males, $51.4 \%$ 20-29 years old, 85.7\% White/Caucasian, 22.1\% Completed some college 22.1\%, Bachelor's degree 26.4\%, Master's degree 18.6\%) respondents participated in the study via online survey platform Prolific. Participants were randomly assigned to conditions in a 2 (advertising type: analytical vs. imagery) x 2 (innovation newness: INP vs. RNP) between subjects experimental design.

Following current literature (Ma, Gill, and Jiang 2015; Roy and Phau 2014; Thompson and Hamilton 2006), four different versions (i.e., imagery and analytical) of an advertisement for the fictitious brand of washing machine 
Turbo were used (see appendix). The advertised brand had three to four attributes varied in terms of innovation newness. All graphic elements, including the size of the picture, were identical across the RNP ads and also across INP ads. We used visual image of INP and RNP from pretest 1.

To manipulate ad type based on the information processing style, we added imagery and analytical cues in the ad messages. Following the current literature (Roy and Phau 2014; Thompson and Hamilton 2006), the imagery ad used short descriptions of new product, while the analytical ad used the same attribute information displayed using a matrix. Both advertisements were similar in terms of the graphics, for example, picture of the washing machine, size of the picture, and colors. The information processing mode of ads varied in the instructions given to participants about how they should process the ad information (Keller and McGill 1994; Roy and Phau 2014; Thompson and Hamilton 2006). In the analytical ads, participants were asked to focus on the attributes and features of the advertised washing machine Turbo and think about how the attributes of the Turbo would meet their needs. In the imagery condition, participants were asked to try to picture the advertised washing machine Turbo in their mind and to imagine as vividly as possible their experience with the washing machine. To ensure that our manipulation affected processing, we measured processing mode based on the questionnaire of Keller and McGill (1994) on 9-point Likert scales.

Results of a pretest $(\mathrm{n}=140)$ confirmed that this manipulation was successful. ANOVAs on innovation newness level measures indicated that RNPs in the RNP ad condition were perceived as more new $\left(\mathrm{M}_{\mathrm{RNP}}=7.778, \mathrm{SD}=\right.$ 1.199, $\mathrm{N}=72$ ), and INPS in the INP ad condition were perceived as less new $\left(\mathrm{M}_{\mathrm{INP}}=\right.$ 5.654, $\mathrm{SD}=1.071, \mathrm{~N}=68),(F(1,138)=$ 2.243, $t=11.027, p<.001)$.

Information processing mode of ads were measured by 9-point items based on Keller and McGill (1994), Roy and Phau (2014), and Thompson and Hamilton (2006). Imagery processing style was measured through three items, "I imagined myself using the Turbo washing machine"; "I savored visions of the Turbo washing machine"; and "I experienced a sense of fun in thinking about the Turbo washing machine" on a 9-point scale with Not very much/A great deal as end points. Analytical processing style measures were consisted of three items, "I evaluated the Turbo washing machine attribute by attribute rather than evaluating it as a whole"; "My evaluation of the Turbo washing machine was based primarily on its features and attributes"; "I carefully evaluated the Turbo washing machine on several different features”. With the same end points. Both the measures showed good reliability (imagery $\alpha=.847$ and analytical $\alpha=.928$, 
respectively).

ANOVAs on advertisement type measures indicated that both the analytical and imagery ads manipulations were successful. The analytical ads generated significantly more analytical processing $\left(\mathrm{M}_{\text {analytical }}=6.887, \mathrm{SD}=1.459\right.$, $\mathrm{N}=68)$ than imagery ads $\left(\mathrm{M}_{\text {imagery }}=3.917\right.$, $\mathrm{SD}=1.238, \mathrm{~N}=72),(F(1,138)=5.511, \mathrm{t}=$ 13.015, $\mathrm{p}<.001$ ), and the imagery ads generated significantly more imagery processing ( $\mathrm{M}_{\text {imagery }}$ $=7.417, \mathrm{SD}=1.123, \mathrm{~N}=72$ ) than the analytical ads $\left(\mathrm{M}_{\text {analytical }}=5.436, \mathrm{SD}=1.891\right.$, $\mathrm{N}=68),(F(1,138)=22.775, t=7.584$, $p<.001)$.

\subsection{Experiment 1}

Study 1 examines whether the advertising type (analytical vs. imagery) has a differential impact on new product evaluation (INPs vs. INPs). We used the combination of picture (visual description) and message (verbal description) of Turbo washing machine in the advertisements.

\subsubsection{Participants and Design}

One hundred and thirty one participants (56.5\% males, $49.6 \%$ 20-29 years old, $28.2 \%$ 30-39 years old, 80.9\% White/Caucasian, 25.2\% Completed some college 22.1\%, Bachelor's degree $31.3 \%$, Master's degree $14.5 \%$ ) responded to the online survey conducted on survey platform
Prolific. Participants were randomly assigned to conditions in a 2 (advertisement format: analytical vs. imagery) x 2 (innovation newness: INPs vs. RNPs) between subjects design. Manipulation checks were identical to those in a pretest.

\subsubsection{Procedures and Measures}

Each participant was randomly allocated to one of the four conditions containing information processing instructions, an ad for the washing machine and a questionnaire. The key dependent variables used for this study were attitude toward the advertisement, product evaluation, and purchase intention, along with other process measures.

Perceived innovation newness was measured by three 9-point items (not at all new/extremely new, not at all novel/extremely novel, not at all innovative/extremely innovative; $\alpha=.934$; Ma, Gill, and Jiang 2015).

Imagery processing and analytical processing were also measured with the same items in the pretest. Both the measures showed good reliability (imagery $\alpha=.882$ and analytical $\alpha=.917$, respectively).

Attitude toward the advertisement was measured using five 9-point scale items - the extent to which subjects considered the advertisement and the product to be bad/good, pleasant/unpleasant, favorable/unfavorable, worthless/valuable, and not interesting/interesting 
(MacKenzie and Lutz 1989; Thompson and Hamilton 2006) ( $\alpha=.888)$.

Product evaluation was measured using five 9-point scale items - the extent to which subjects considered the product to be bad/good, not at all desirable/desirable, unattractive/ attractive, negative/positive, don't like it at all/like it very much (MacKenzie and Lutz 1989; Roy and Phau 2014; Thompson and Hamilton 2006) ( $\alpha=.954)$.

Purchase intention was measured using two 9-point scale items - How interested will you be in buying the Turbo? $\quad(1=$ not at all interested, $9=$ extremely interested), How likely is that you will buy the Turbo? $(1=$ not at all likely, $9=$ extremely likely) ( $\mathrm{Ma}$, Gill, and Jiang 2015) ( $\alpha=.900)$.

Trait newness was measured with two 9point items such as "I am usually among the first to try new products." and "I like to buy new and different things." anchored at $1=$ strongly disagree, $9=$ strongly agree." ( $\mathrm{Ma}$, Gill, and Jiang 2015) ( $\alpha=.755)$.

In addition, single-item of 9-point scales were used to gauge involvement (how important) and familiarity (how familiar) with the product category.

\subsubsection{Manipulation Checks Results}

Participants' ratings on innovation newness level measures indicated that RNPs in the RNP ad condition were perceived as more new
$\left(\mathrm{M}_{\mathrm{RNP}}=7.708, \mathrm{SD}=1.406, \mathrm{~N}=65\right)$, and INPS in the INP ad condition were perceived as less new $\left(\mathrm{M}_{\mathrm{INP}}=5.349, \mathrm{SD}=.900, \mathrm{~N}=\right.$ $66),(F(1,129)=8.045, t=11.455, p<.001)$.

ANOVAs on advertisement type measures indicated that both the analytical and imagery ads manipulations were successful. The analytical ads generated significantly more analytical processing $\left(\mathrm{M}_{\text {analytical }}=7.046, \mathrm{SD}=1.309, \mathrm{~N}=\right.$ 66) than imagery ads $\left(\mathrm{M}_{\text {imagery }}=4.308, \mathrm{SD}=\right.$ 1.194, $\mathrm{N}=65),(F(1,129)=2.237, t=$ $12.505, p<.001$ ), and the imagery ads generated significantly more imagery processing ( $\mathrm{M}_{\text {imagery }}$ $=7.313, \mathrm{SD}=1.077, \mathrm{~N}=65$ ) than the analytical ads $\left(\mathrm{M}_{\text {analytical }}=4.914, \mathrm{SD}=1.704\right.$, $\mathrm{N}=66),(F(1,129)=14.029, t=9.615$, $p<.001)$.

\subsubsection{Results}

The results of a one-way ANOVA showed that familiarity, involvement with the category, trait newness, and demographic variables such as age, gender, education, income did not differ across conditions (all p’s $>$.10). Thus, they were dropped from further statistical analyses.

The three major dependent variables - attitude toward the advertisement, product evaluation, and purchase intention - were subjected to a MANOVA. There was no main effects of advertisement types or innovation newness. However, as expected, there was significant interaction effect between innovation newness 
and ad type for all dependent variables ( $F$ $(3,125)=5.940, p<.001$, Wilks' $\Lambda=.875)$.

We compared the cell means by t-tests. In case of the RNP, we predicted that the imagery ad would elicit more positive ad evaluations $\left(\mathrm{M}_{\text {imagery }}=7.200\right.$ and $\mathrm{M}_{\text {analytical }}=6.074, F(1,63)$ $=10.523, t=3.731, p=.000)$, more positive product evaluations $\left(M_{\text {imagery }}=7.700\right.$ and $\mathrm{M}_{\text {analytical }}=6.891, F(1,63)=6.324, t=2.061$, $p=.043)$, and greater purchase intentions $\left(\mathrm{M}_{\text {imagery }}=7.000\right.$ and $\mathrm{M}_{\text {analytical }}=5.457, F(1,63)$ $=2.768, t=3.647, p=.001$ ) than the analytical ad. In contrast, for the INP, we predicted that the analytical ad would increase attitude toward ad, product, and purchase intention. However, there was no difference between the two types of advertisements on the INP for ad evaluations $\left(\mathrm{M}_{\text {imagery }}=6.046\right.$ and $\mathrm{M}_{\text {analytical }}=6.426, F(1,64)=.604, t=$ $.976, p=.333)$, product evaluations $\left(\mathrm{M}_{\text {imagery }}=\right.$ 6.406 and $\mathrm{M}_{\text {analytical }}=7.116, F(1,64)=.537$, $t=1.601, p=.114)$. However, there was significant differences for purchase intentions for the INP. Compared with imagery advertisement, analytical advertisement increased purchase intention of the INP $\left(\mathrm{M}_{\text {imagery }}=5.200\right.$ and $\mathrm{M}_{\text {analytical }}=6.177, F(1,64)=.477, t=2.128$, $p=.037$ ). Please refer to Table 1 and Figure 1. These results support $\mathrm{H} 1$ and $\mathrm{H} 2$, and partially support H3.

\subsubsection{Discussion}

The results of first study showed that imagery ad (vs. analytical ad) led to better attitude toward advertisement and product evaluation for the RNP, and it ultimately resulted in a higher purchase intention. Study 1 showed that compared with analytical ad, imagery ad improved the evaluation rating of attitude toward ad and product evaluation of the RNP, but the two types of ad had no differences on the attitude toward ad and product evaluation of the INP, which provides initial support for $\mathrm{H} 1$ and $\mathrm{H} 2$. In addition, imagery (vs. analytical) ad increased purchase intention of the RNP, whereas analytical (vs. imagery) ad increased purchase intention of the INP, which partially support H3. The interaction effect identified also indicated that

〈Table 1〉 Study 1 Dependent Variables as a Function of Innovation Newness and Ad Type

\begin{tabular}{|c|c|c|c|c|c|c|}
\hline \multirow[b]{2}{*}{ Variables } & \multicolumn{2}{|c|}{ Attitude toward Ad } & \multicolumn{2}{|c|}{ Product Evaluation } & \multicolumn{2}{|c|}{ Purchase Intention } \\
\hline & Imagery ad & Analytical ad & Imagery ad & Analytical ad & Imagery ad & Analytical ad \\
\hline $\begin{array}{c}\text { RNP } \\
(\mathrm{n}=65)\end{array}$ & $\begin{array}{l}7.200 \\
(0.714)\end{array}$ & $\begin{array}{l}6.074 \\
(1.513)\end{array}$ & $\begin{array}{l}7.700 \\
(1.034)\end{array}$ & $\begin{array}{l}6.891 \\
(1.922)\end{array}$ & $\begin{array}{l}7.000 \\
(1.287)\end{array}$ & $\begin{array}{l}5.457 \\
(1.987)\end{array}$ \\
\hline $\begin{array}{c}\mathrm{INP} \\
(\mathrm{n}=66)\end{array}$ & $\begin{array}{l}6.046 \\
(1.483)\end{array}$ & $\begin{array}{l}6.426 \\
(1.682)\end{array}$ & $\begin{array}{l}6.406 \\
(1.720)\end{array}$ & $\begin{array}{l}7.116 \\
(1.884)\end{array}$ & $\begin{array}{l}5.200 \\
(1.868)\end{array}$ & $\begin{array}{l}6.177 \\
(1.855)\end{array}$ \\
\hline
\end{tabular}

Note: $N=131$ participants. Standard deviations are in parentheses. 
〈Figure 1〉 The Role of Innovation Newness in the Relationship between Ad Type and Dependent Variables
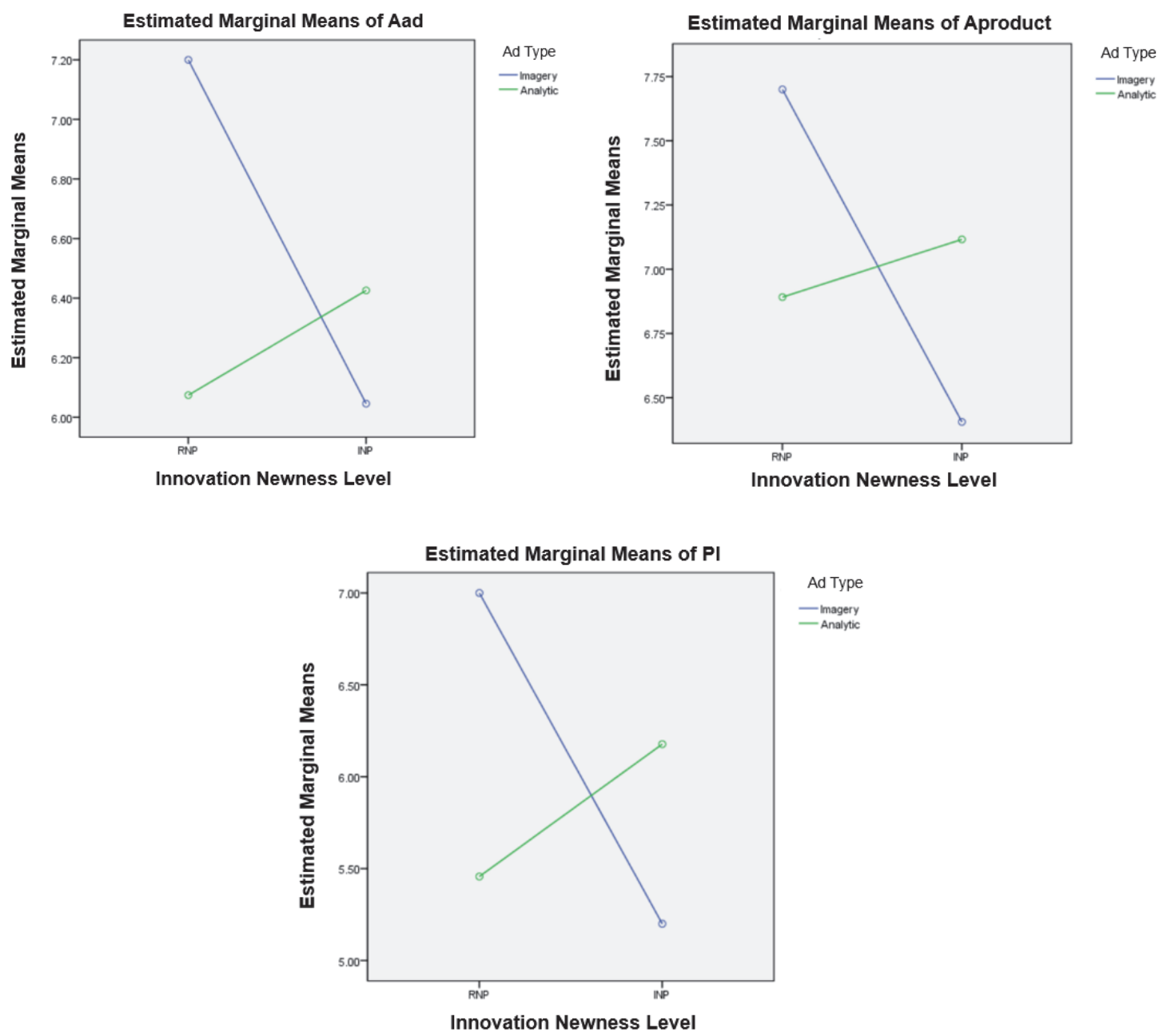

the results were driven by the differences in how the attributes and benefits were described for the RNP and INP, because participants in both the imagery and analytical ad conditions saw the same product stimuli but different manipulations of messages.

One limitation of study 1 is that we used both verbal description (message) and visual description (picture) of new products in the ads. To test the robustness of the impact of imagery ad on the positive evaluation of the RNP, in study 2, we conducted an experiment in the absence of pictures (Bone and Ellen 1992; Roy and Phau 2014). 


\section{Study 2. Car}

\subsection{Pretest for Product Stimuli}

\subsubsection{Pretest. Verbal Description (Message) of Stimuli}

One hundred and nineteen participants (55.5\% males, 52.1\% 20-29 years old, 10.9\% 30-39 years old, 61.3\% White/Caucasian/ 10.1\% Asian, 16.8\% Completed some college 22.1\%, Bachelor's degree 27.7\%, Master's degree 7.6\%) responded to the online survey conducted on survey platform Prolific. Participants were randomly assigned to conditions in a 2 (advertising type: analytical vs. imagery) x 2 (innovation newness level: INP vs. RNP) between subjects experimental design.

To identify an appropriate stimulus, four different versions (i.e., imagery and analytical) of an advertisement for the fictitious brand of car "Allegre" were developed (Ma, Gill, and Jiang 2015; Thompson and Hamilton 2006; Roy and Phau 2014). The flying car was chosen as there have been several announcements by major automakers of introducing a "flying taxi." To test the pure impact of imagery ad on the positive evaluation of the RNP, we conducted experiment 2 with verbal description only ads in the absence of images. The advertised brand had three to four attributes varied in terms of innovation newness level.
We manipulated imagery ad by inserting short descriptive statements (imagery cue) (e.g., you enter the curve, feel the grip of the seat and enjoy morning sunrays" (Roy and Phau 2014: Thompson and Hamilton 2006; Unnava and Burnkrant 1991). An analytical ad was manipulated by adding a matrix displaying attribute information (analytical cue). The stimuli are presented in appendix.

Perceived innovation newness was measured by three 9-point items (not at all new/extremely new, not at all novel/extremely novel, not at all innovative/extremely innovative; $\alpha=$ .864; Ma, Gill, and Jiang 2015). ANOVAs on innovation newness level measures indicated that RNPs in the RNP ad condition were perceived as more new $\left(\mathrm{M}_{\mathrm{RNP}}=7.517, \mathrm{SD}=\right.$ 1.108, $\mathrm{N}=59$ ), and INPs in the INP ad condition were perceived as less new $\left(\mathrm{M}_{\mathrm{INP}}=\right.$ 5.642, $\mathrm{SD}=1.000, \mathrm{~N}=60),(F(1,117)=$ $.874, t=9.263, p<.001)$.

To ensure that our manipulation of imagery vs. analytical ad was successful, we measured processing mode of each ad based on the questionnaire of Keller and McGill (1994) on 9-point Likert scales (Roy and Phau 2014; Thompson and Hamilton 2006). ANOVAs on the advertisement type measures indicated that both the analytical and imagery ads manipulations were successful. The analytical ads generated significantly more analytical processing $\left(\mathrm{M}_{\text {analytical }}=6.989, \mathrm{SD}=1.002, \mathrm{~N}=\right.$ 59) than imagery ads $\left(\mathrm{M}_{\text {imagery }}=4.439, \mathrm{SD}=\right.$ 
1.057, $\mathrm{N}=60),(F(1,117)=.173, t=13.503$, $p<.001)$, and the imagery ads generated significantly more imagery processing $\left(\mathrm{M}_{\text {imagery }}\right.$ $=6.950, \mathrm{SD}=1.099, \mathrm{~N}=60)$ than the analytical ads $\left(\mathrm{M}_{\text {analytical }}=3.910, \mathrm{SD}=1.567\right.$, $\mathrm{N}=59),(F(1,117)=7.527, t=12.270$, $p<.001)$. Reliability for imagery scales was $\alpha=.905$. And analytical scales reliability was $\alpha=.858$.

\subsection{Experiment 2}

Study 2 tested the robustness of imagery ad's positive effect on RNPs in the absence of pictures (Bone and Ellen 1992: Roy and Phau 2014). This would allow more rigorous test of hypothesis and allow us to test whether the preference for one type of ad over another is relative or absolute. In essence, we wanted to not only replicate the results of our first study but also extended it further in terms of theory and application.

\subsubsection{Participants and Design}

One hundred and twenty two participants (62.3\% males, $58.2 \%$ 20-29 years old, 23\% 30-39 years old, $78.7 \%$ White/Caucasian, 19.7\% Completed some college, 23\%, Bachelor's degree, 22.1\% Master's degree $14.5 \%$ ) responded to the online survey conducted on survey platform Prolific. Participants were randomly assigned to conditions in a 2 (advertisement format: analytical vs. imagery) x 2 (innovation newness: INPs vs. RNPs) between subjects design.

\subsubsection{Procedures and Measures}

In experiment 2, a fictitious brand of car "Allegre" was used as the product category. And imagery versus analytical message characteristics were manipulated through product descriptions (Bolls and Muehling 2007; Bone and Ellen 1992; Roy and Phau 2014). Each participant was randomly allocated to one of the four conditions containing information processing instructions, an ad for the Allegre flying car / hybrid car and a questionnaire. The key dependent variables used for this study were attitude toward the advertisement, product evaluation, purchase intention, and message persuasiveness, along with other measures. Manipulation checks were identical to those in a pretest.

Perceived innovation newness was measured by three 9-point items (not at all new/extremely new, not at all novel/extremely novel, not at all innovative/extremely innovative; $\alpha=$ .910; Ma, Gill, and Jiang 2015).

Based on the questionnaire of Keller and McGill (1994) on 9-point Likert scales, we measured manipulation check of each ad (Roy and Phau 2014; Thompson and Hamilton 2006; Oliver, Robertson and Mitchell 1993). Imagery ad manipulation was measured through three items, namely, "I imagined myself using 
this new Allegre flying car / hybrid car”; "I savored visions of the new Allegre flying car / hybrid car"; "I experienced a sense of fun in thinking about the new Allegre flying car / hybrid car”. Analytical ad manipulation was measured through three items, "I evaluated the new Allegre flying car/ hybrid car attribute by attribute rather than evaluating it as a whole"; "My evaluation of the new Allegre flying car / hybrid car was based primarily on its features and attributes"; "I carefully evaluated the Allegre flying car / hybrid car on several different features". Both the measures showed good reliability (imagery $\alpha=.900$ and analytical $\alpha=.882$, respectively).

Attitude toward the advertisement was measured using five 9-point scale items - the extent to which subjects considered the advertisement and the product to be bad/ good, pleasant/unpleasant, favorable/unfavorable, worthless/valuable, and not interesting/interesting ( $\alpha=$.896) (MacKenzie and Lutz 1989; Thompson and Hamilton 2006).

Product evaluation was measured using five 9-point scale items - the extent to which subjects considered the product to be bad/good, not at all desirable/desirable, unattractive/ attractive, negative/positive, don't like it at all/like it very much ( $\alpha=.916$ ). (MacKenzie and Lutz 1989; Roy and Phau 2014; Thompson and Hamilton 2006)

Purchase intention was measured using two 9-point scale items - How interested will you be in buying the Allegre flying car / hybrid car? $(1=$ not at all interested, $9=$ extremely interested), How likely is that you will buy the Allegre flying car / hybrid car? ( $1=$ not at all likely, 9 =extremely likely) $(\alpha=.797)$. (Ma, Gill, and Jiang 2015)

Message persuasiveness was measured by asking participants to rate the message as being not persuasive / persuasive, providing weak / strong arguments/ and containing unimportant / important information (Roy and Phau 2014; Thompson and Hamilton 2006). All three measures were nine-point scales $(\alpha=.766)$.

Trait newness was measured with two 9point items such as "I am usually among the first to try new products." and "I like to buy new and different things." anchored at $1=$ strongly disagree, $9=$ strongly agree." ( $\mathrm{Ma}$, Gill, and Jiang 2015) ( $\alpha=.766)$.

In addition, single-item of 9-point scales were used to gauge involvement (how important) and familiarity (how familiar) with the product category.

\subsubsection{Manipulation Checks Results}

Participants' ratings on innovation newness level measures indicated that RNPs in the RNP ad condition were perceived as more new $\left(\mathrm{M}_{\mathrm{RNP}}=7.421, \mathrm{SD}=1.258, \mathrm{~N}=60\right)$, and INPs in the INP ad condition were perceived as less new $\left(\mathrm{M}_{\mathrm{INP}}=5.165, \mathrm{SD}=1.245, \mathrm{~N}=\right.$ 
62), $(F(1,120)=1.186, t=9.949, p<.001)$.

ANOVAs on advertisement type measures indicated that both the analytical and imagery ads manipulations were successful. The analytical ads generated significantly more analytical processing $\left(\mathrm{M}_{\text {analytical }}=6.863, \mathrm{SD}=1.074, \mathrm{~N}=\right.$ 61) than imagery ads ( $\mathrm{M}_{\text {imagery }}=4.366, \mathrm{SD}=$ 1.239, $\mathrm{N}=61),(F(1,120)=.084, t=11.894$, $p<.001)$, and the imagery ads generated significantly more imagery processing $\left(\mathrm{M}_{\text {magery }}=\right.$ $6.667, \mathrm{SD}=1.200, \mathrm{~N}=61$ ) than the analytical ads $\left(\mathrm{M}_{\text {analytical }}=4.164, \mathrm{SD}=1.509, \mathrm{~N}=61\right)$, $(F(1,120)=2.118, t=10.139, p<.001)$.

\subsubsection{Results}

The results of a one-way ANOVA showed that familiarity, involvement with the category, trait newness, and demographic variables including age, gender, education, income did not differ across conditions (all p's $>$.10). Thus, they were eliminated from further statistical analyses.

The four major dependent variables - attitude toward the advertisement, product evaluation, purchase intention, and message persuasiveness - were subjected to a MANOVA. As expected, there were significant interactions between innovation newness and ad type for all dependent variables $(F(3,116)=6.996, p<.001$, Wilks' $\Lambda=.847)$.

We conducted a $2 \times 2$ analysis of variance and found that there were main effect of innovation newness level $(F(1,118)=5.101$, $\mathrm{p}=.026)$ or advertisement type $(F(1,118)=$ $14.226, \mathrm{p}=.026)$. And as we predicted, there were significant interactions between innovation newness level and advertisement type ( $F(1,118)$ $=9.298, \mathrm{p}=.003)$. Imagery advertisement increased participants' positive attitude toward ad for the RNP compared with analytical advertisement $\left(\mathrm{M}_{\text {imagery }}=7.028\right.$ and $\mathrm{M}_{\text {analytical }}=$ 5.458, $F(1,58)=1.100, \mathrm{t}=4.720, \mathrm{p}=.000)$, whereas there was no difference between the two types of advertisements on participants' attitude toward ad for the INP ( $\mathrm{M}_{\text {imagery }}=5.806$ and $\mathrm{M}_{\text {analytical }}=5.640, F(1,60)=20.132, \mathrm{t}=$ $.522, \mathrm{p}=.604)$. Imagery advertisement increased participants' evaluation of the RNP compared with analytical advertisement $\left(\mathrm{M}_{\text {imagery }}=7.503\right.$ and $\mathrm{M}_{\text {analytical }}=6.019, F(1,58)=1.766, \mathrm{t}=$ $4.447, \mathrm{p}=.000$ ), whereas there was no difference between the two types of advertisements on participants' evaluation for the INP $\left(\mathrm{M}_{\text {imagery }}=\right.$ 5.969 and $\mathrm{M}_{\text {analytical }}=6.560, F(1,60)=12.539$, $\mathrm{t}=1.812, \mathrm{p}=.494)$. Imagery advertisement increased participants' purchase intention of the RNP compared with imagery advertisement $\left(\mathrm{M}_{\text {imagery }}=6.862\right.$ and $\mathrm{M}_{\text {analytical }}=4.807, F(1,58)$ $=.373, \mathrm{t}=5.329, \mathrm{p}=.000$ ), whereas analytical advertisement increased participants' purchase intention for the INP ( $\mathrm{M}_{\text {imagery }}=4.734$ and $\mathrm{M}_{\text {analytical }}=4.433, F(1,60)=3.802, \mathrm{t}=.688$, $\mathrm{p}=.494)$. Message persuasiveness also showed a similar pattern of results. The imagery advertisement increased message persuasiveness 
of ad for the RNP compared with analytical advertisement $\left(\mathrm{M}_{\text {imagery }}=6.517\right.$ and $\mathrm{M}_{\text {analytical }}=$ 5.667, $F(1,58)=.000, \mathrm{t}=2.056, \mathrm{p}=.044)$, whereas there was no difference between the two types of advertisements on message persuasiveness of ad for the INP $\left(\mathrm{M}_{\text {imagery }}=\right.$ 5.615 and $\mathrm{M}_{\text {analytical }}=5.367, F(1,60)=5.038$, $\mathrm{t}=.684, \mathrm{p}=.497)$. A similar pattern of results was thus obtained in study 2 with respect to key hypothesis and support was also provided for our fourth hypothesis on message persuasiveness. All the means are reported in Table 2 and Figure 2. These results support $\mathrm{H} 1, \mathrm{H} 2, \mathrm{H} 3$, and $\mathrm{H} 4$.

〈Table 2〉 Study 2 Dependent Variables as a Function of Innovation Newness and Ad Type

\begin{tabular}{|c|c|c|c|c|c|c|c|c|}
\hline \multirow[b]{2}{*}{ Variables } & \multicolumn{2}{|c|}{ Attitude toward Ad } & \multicolumn{2}{|c|}{ Product Evaluation } & \multicolumn{2}{|c|}{ Purchase Intention } & \multicolumn{2}{|c|}{ Message Persuasiveness } \\
\hline & Imagery ad & Analytical ad & Imagery ad & Analytical ad & Imagery ad & Analytical ad & Imagery ad & Analytical ad \\
\hline $\begin{array}{c}\mathrm{RNP} \\
(\mathrm{n}=60)\end{array}$ & $\begin{array}{l}7.028 \\
(1.195)\end{array}$ & $\begin{array}{l}5.458 \\
(1.367)\end{array}$ & $\begin{array}{l}7.503 \\
(1.395)\end{array}$ & $\begin{array}{l}6.019 \\
(1.188)\end{array}$ & $\begin{array}{l}6.862 \\
(1.499)\end{array}$ & $\begin{array}{l}4.807 \\
(1.487)\end{array}$ & $\begin{array}{l}6.517 \\
(1.675)\end{array}$ & $\begin{array}{l}5.667 \\
(1.530)\end{array}$ \\
\hline $\begin{array}{c}\mathrm{INP} \\
(\mathrm{n}=62)\end{array}$ & $\begin{array}{l}5.806 \\
(0.659) \\
\end{array}$ & $\begin{array}{l}5.640 \\
(1.669)\end{array}$ & $\begin{array}{l}5.969 \\
(0.742)\end{array}$ & $\begin{array}{l}6.560 \\
(1.680)\end{array}$ & $\begin{array}{l}4.734 \\
(1.362)\end{array}$ & $\begin{array}{l}4.433 \\
(2.037)\end{array}$ & $\begin{array}{l}5.615 \\
(1.164)\end{array}$ & $\begin{array}{l}5.367 \\
(1.662)\end{array}$ \\
\hline
\end{tabular}

Note: $N=122$ participants. Standard deviations are in parentheses.

〈Figure 2〉 Study 2 Interaction Effect of Innovation Newness Level and Ad Type
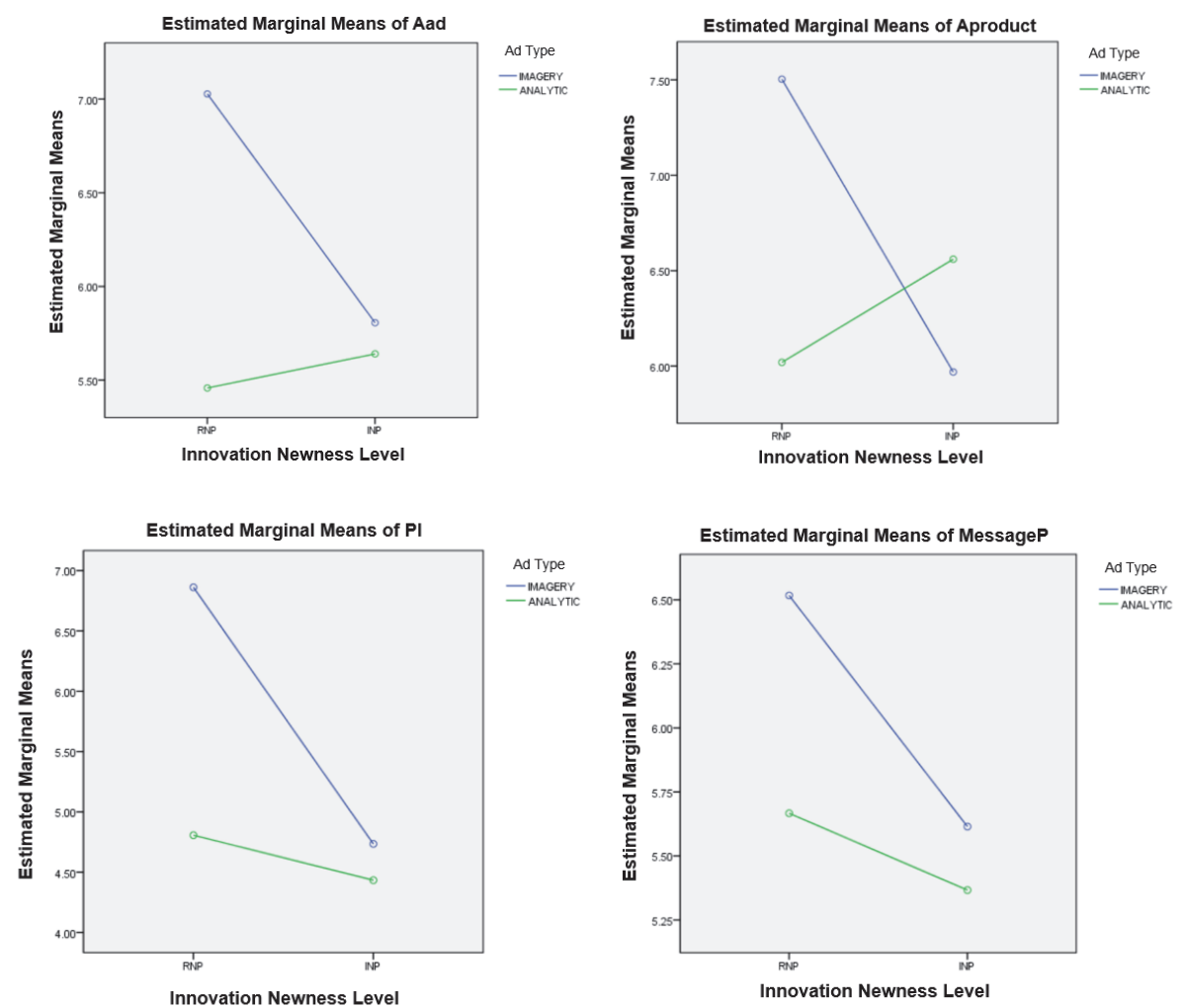

76 ASIA MARKETING JOURNAL Vol. 22 No. 02 July 2020 


\subsubsection{Discussion}

The results of Study 2 provide support for all the key hypotheses in the research. Using a different product category and advertisement manipulation, the results showed that advertising the RNP with an imagery cue increased ad effectiveness, product evaluation, and purchase intention for the RNP. Furthermore, the interaction of advertisement type and innovation newness had an effect, of increasing the message persuasiveness of image type ads of RNPs to a greater extent. These findings also showed that depending on the level of innovation newness of products, one style of ad type is usually preferred more than the other. Specifically, the results revealed that using imagery (vs. analytical) ad was more effective communication strategy to promote the RNP.

\section{General Discussion}

The primary purpose of this research was to identify the role of innovation newness in product evaluation. Across two experiments, the results revealed that compared with analytical ads, imagery ads increased ad effectiveness, product evaluation, and purchase intention of RNPs. Furthermore, advertising message was more persuasive when RNPs were advertised with the imagery information. Furthermore, imagery cue increased message persuasiveness of the RNP ad. There were convergent and robust evidence across two studies in this regard using different dependent measures (attitude toward ads, product evaluation, purchase intention in Study 1 and message persuasiveness in Study 2), using different advertisement manipulations (verbal and visual description in Study 1 versus verbal description only in Study 2), and across different product categories (washing machine and car).

This study makes important theoretical contributions. First of all, it contributes to the new product innovation literature, as this work has established the fit between the RNP and imagery ads. In terms of imagery literature, this study provides evidence of innovation newness as a moderator of imagery and analytical processing, thereby answering the call to undertake more divergent psychological research on imagery processing (e.g., Bone and Ellen 1992: Keller and McGill 1994; MacInni and Price 1987; Petrova and Cialdini 2005, Oliver, Robertson, and Mitchell 1993, Roy and Phau 2014; Thompson and Hamilton 2006). The study also shows the moderating role of product innovativeness in the positive effects of imagery elicitation (e.g., imaging instructions). While prior research on the imagery processing or mental simulation has reported a positive role of imagery visualization (e.g., Esacalas 2004; Philips 1996: Shiv and Huber 2000), our 
study shows that this only holds for RNPS. Namely, in this research, we emphasized the relative importance of imagery processing only in RNPs. The results showed that exposing RNPs to imagery (vs. analytical) message led to increased product evaluation of RNPs (Zhao, Hoeffler, and Dahl 2009), whereas there was no differential impact of the two types of message on the evaluation of INPS.

There are several practical implications for managers. The results suggest that there are specific situations that warrant different advertisement execution styles. For example, a car advertisement may decide to focus on imagery information providing new benefits and usage scenarios versus an analytical information focusing on product attributes by attributes. Matching advertisement style with an innovation newness level may increase the effectiveness of the advertisement.

For example, an advertisement for the radically innovative product such as a flying car may make imagery processing salient by focusing the end benefits with descriptions and metaphors. When marketing RNPs, mangers should encourage consumers to use their imagination and focus on new uses and benefits they have never experienced before (Zhao, Hoeffler, and Dahl 2009). In their printed brochures, television commercials, or Web advertisements, managers could encourage consumers to imagine new benefits and uses of RNPs they have never experienced before.
Advertisers may, however, benefit from having both types of advertisement (e.g., imagery and analytical) for the incrementally innovative product such as a hybrid car.

This research has limitations. In an extant literature, imagery is closely linked to affect (Oliver, Robertson, and Mitchell 1993), which may indirectly suggest this as a potential confound in the study (Roy and Phau 2014). However, considerable amount of literature supports that the operationalization of message characteristics using promotion, hedonic, and imagery features in advertisements does not manipulate affect in subjects (Bolls and Muehling 2007; Labroo and Lee 2006; Thompson and Hamilton 2006). Another limitation is that the amount of information presented in the analytical and images ads were not equal, and novel ways to equate the same amount of information is needed in future studies.

This study results need to be replicated across wider product categories and samples, although products used in this study, such as washing machine and car, were relevant and familiar. The advertisements used in the first study have both visual and verbal elements that complement each other. Future work may further explore how innovation newness level may affect evaluations of comparative and non-comparative advertisements (Kalro, Sivakumaran, and Marathe 2013; Thompson and Hamilton 2006). We used a product information sheet as stimuli. Future research 
may investigate if these results will generate to other product information mediums such as TV commercials or radio commercials.

Future investigations should test for mediators to verify the underlying mechanism of the study results. A list of constructs such as information processing fluency (Cho 2013; Lee and Labroo 2004; Petrova and Cialdini 2005), familiarity (Lee and Chu 2020), perceived risk (Lee and Chu 2020; Ma, Gill, and Jiang 2015), cognitive resolution (Noseworthy, Murray, and Di Muro 2018) and positive affect (Jhang, Grant, and Campbell 2012) may underlie the effectiveness of new product advertisements on the RNPs. Further, one can investigate other characteristics of imagery processing that are relevant to new product evaluation, such as vividness (Petrova and Cialdini 2005), and the depth of the mental simulation (Escalas and Luce 2004; Yoo and Song 2010). More generally, research on the different cognitive strategies that consumers employ when understanding and evaluating new product offerings would be beneficial.

〈Received June 15. 2020〉

$\langle$ Accepted July 24. 2020〉

\section{References}

Alexander, David L., John G. Lynch Jr. and Qing Wang (2008), “As Time Goes By:
Do Cold Feet Follow Warm Intentions for Really New versus Incrementally New Products?" Journal of Marketing Research, 45(3), 307-319.

Bettman, James, Mary F. Luce, and John Payne (1998), “Constructive Consumer Choice Processes," Journal of Consumer Research, 25(3), 187-217.

Bolls, Paul D. and Darrel D. Muehling (2007), "The Effects of Dual Task Processing on Consumers' Responses to High- and LowImagery Radio Advertisements," Journal of Advertising, 36(4), 35-47.

Bone, P. Fitzgerald and Pam S. Ellen (1992), "The Generation and Consequences of Communication-Evoked Imagery," Journal of Consumer Research, 19(1), 93-104.

Burke, Marian Chapman and Julie A. Edell (1989), "The Impact of Feelings on AdBased Affect and Cognition," Journal of Marketing Research, 26(February), 69-83. Castano, Raquel, Mita Sujan, Manish Kacker, and Harish Sujan (2008), “Managing Consumer Uncertainty in the Adoption of New Products: Temporal Distance and Mental Simulation," Journal of Marketing Research, 45(3), 320-336.

Childers, Terry L., Michael J. Houston, and Sujan E. Heckler (1985), “Measurement of Individual Differences in Visual versus Verbal Information Processing," Journal of Consumer Research, 12(2), 125-134.

Cho, Hye Jeung (2013), “The Role of Processing 
Fluency in Product Innovativeness Judgment," Asia Marketing Journal, 15(3), 31-52.

Dahl, Darren W., Amitava Chattopadhyay, and Gerald J. Gorn (1999), "The Use of Visual Mental Imagery in New Product Design," Journal of Marketing Research, 36(1), 18-28.

Dahl, Darren W. and Steve Hoeffler (2004), "Visualizing the Self: Exploring the Potential Benefits and Drawbacks for New Product Evaluation," Journal of Product Innovation Management, 21, 259-267.

Edell, Julie A. and Richard Staelin (1983), "The Information Processing of Pictures in Print Advertisements," Journal of Consumer Research, 10(June), 45-61.

Escalas, J. Edson (2004), "Imagine Yourself in the Product: Mental Simulation, Narrative Transportation, and Persuasion," Journal of Advertising, 33(2), 37-48.

Escalas, J. Edson and Mary F. Luce (2004), "Understanding the Effects of ProcessFocused Versus Outcome-Focused Thought in Response to Advertising," Journal of Consumer Research, 31(2), 274-285.

Feiereisen, S., V. Wong, and A. J. Broderick (2008), "Analogies and Mental simulations in Learning for Really New Products: The Role of Visual Attention," Journal of Product Innovation Management, 25, 593607.

Fischoff, Baruch (1991), "Value Elicitation: Is there Anything in There?" American
Psychologist, 46(8), 835-846. Gasper, Karen (2004), “Do You See What I see? Affect and Visual Information Processing," Cognitive and Emotion, 18 (3), 405-421.

Garcia, Rosanna and Roger Calatone (2002), "A Critical Look at Technological Innovation Typology and Innovativeness Terminology: A Literature Review," Journal of Product Innovation Management, 19(2), 110-132.

Gregan-Paxton, Jennifer and Page Moreau (2003), "How Do Consumers Transfer Existing Knowledge? A comparison of Analogy and Categorization Effects," Journal of Consumer Psychology, 13(4), 422-430. Hauser, John, Gerard J. Tellis, and Abbie Griffin (2006), "Research on Innovation: A Reivew and Agenda for Marketing," Marketing Science, 25(6), 687-717.

Hoeffler, Steve (2003), "Measuring Preferences for Really New Products," Journal of Marketing Research, 40(4), 406-420.

Jhang, Ji Hoon, Susan Jung Grant, and Margaret C. Campbell (2012), "Get it? Got it. Good! Enhancing New Product Acceptance by Facilitating Resolution of Extreme Incongruity," Journal of Marketing Research, 49(2), 247-259.

Kalro, Arti D., Bharadawaj Sivakumaran, and Rahul R. Marathe (2013), "Direct or Indirect Comparative Ads: The Moderating Role of Information Processing Modes," Journal of Consumer Behaviour, 12, 133-147. 
Keller, Punam A., and Lauren G. Block (1997), "Vividness Effects: A Resource Matching Perspective," Journal of Consumer Research, 24(3), 295-304.

Keller, Punam A. and Ann L. McGill (1994), "Differences in the Relative Influence of Product Attributes under Alternative Processing Conditions: Attribute Importance versus Attribute Ease of Imaginability," Journal of Consumer Psychology, 3(1), 29-49.

Kisielius, Jolita, and Brian Sternthal (1986), "Examining the Vividness Controversy: An Availability-Valence Interpretation," Journal of Consumer Research, 12(4), 418-431.

Labroo, Aparna A., and Angela Y. Lee (2006), "Between Two Brands: A Goal Fluency Account of Brand Evaluation," Journal of Marketing Research, 43(3), 374-385.

Lee, Angela Y. and Aparna A. Labroo (2004), "The Effect of Conceptual and Perceptual Fluency on Brand Evaluation," Journal of Marketing Research, 41(2), 151-165.

Lee, Juyon and Wujin Chu (2020), "The Effects of Innovation Newness on Consumers' Purchase Intention: Focusing on the Mediating Role of Familiarity and Perceived Risk and the Moderating Role of Attributes vs. Benefits Appeal," Korea Journal of Marketing, 35(1), 97-117.

Lehman, Don (1997), “A Different Game: Setting the Stage," Paper presented at
MSI Conference. A Different Game: Really New Products, Evolving Markets, and Retrospective Organizations, Boston, MA, March 16-18.

Ma, Zhenfeng, Tripat Gill, and Ying Jiang (2015), "Core versus Peripheral Innovations: The Effect of Innovation Locus on Consumer Adoption of New Products," Journal of Marketing Research, 52(3), 309-324.

Mani, Gayathri, and Deborah J. MacInnis (2001), "Imagery Instructions, Imagery Processes and Visual Persuasion," in Advertising and Consumer Psychology, R. Batra and O. Scott, eds., Lexington, MA: Lexington Books.

MacInnis, Deborah J. and Linda L. Price (1987), "The Role of Imagery in Information Processing: Review and Extensions," Journal of Consumer Research, 13(4), 473-491.

MacKenzie, Scott and Richard Lutz (1987), “An Empirical Examination of the Structural Antecedents of Attitude toward the Ad in an Advertising Pretesting Context," Journal of Marketing, 53(April), 48-65.

Mukherjee, Ashesh and Wayne D. Hoyer (2001), "The Effect of Novel Attributes on Product Evaluation," Journal of Consumer Research, 28(3), 462-472.

Noseworthy, Theodore J., June Cotte, and Seung Hwan (Mark) Lee (2011), “The Effects of Ad Context and Gender on the Identification of Visually Incongruent Products," Journal of Consumer Research, 38(2), 358-375. 
Noseworthy, Theodore J, Kyle B Murray, and Fabrizio Di Muro (2018), "When Two Wrongs Make a Right: Using Conjunctive Enablers to Enhance Evaluations for Extremely Incongruent New Products," Journal of Consumer Research, 44(6), 1319-1396.

Oliver, Richard L., Thomas S. Robertson and Deborah J. Mitchell (1993), "Imaging and Analyzing in Response to New Product Advertising," Journal of Advertising, 22 (4), 35-50.

Ostlund, Lymman E. (1974), "Perceived Innovation Attributes as Predictors of Innovativeness," Journal of Consumer Research, 1(2), 23-29. Payne, John W. James R. Bettman, and Eric J. Johnson (1992), "Behavioral Decision Research: A Constructive Processing Approach," Annual Review of Psychology, 43, 87-131.

Petrova, Petia K. and Robert B. Cialdini (2005), "Fluency of Consumption Imagery and the Backfire Effects of Imagery Appeals," Journal of Consumer Research, 32(3), $442-452$.

Phillips, Diane (1996), "Anticipating the Future: The Role of Consumption Visions in Consumer Behavior. In: Advances in Consumer Research. M. Brucks and D. J. MacInnis (eds.), Provo, UT: Association for Consumer Research, 70-75.

Rogers, Everett (2003), Diffusion of Innovations. New York: Simon and Schuster.
Roy, Rajat and Ian Phau (2014), "Examining Regulatory Focus in the Information Processing of Imagery and Analytical Advertisements," Journal of Advertising, 43(4), 371-381.

Shiv, Baba and Joel Huber (2000), “The Impact of Anticipating Satisfaction on Consumer Choice," Journal of Consumer Research, 27 (2), 202-216.

Slovic, Paul (1995), "The Construction of Preference," American Psychologist, 50(5), 364-371.

Smith, Pamela K., and Yaacov Trope (2006), "You Focus on the Forest When You Are in Charge of Trees: Power Priming and Abstract Information Processing," Journal of Personality and Social Psychology, 90 (4), 578-596.

Smith, Terrence R., Andrew A. Mitchell, and Robert Meyer (1982), “A Computational Process Model of Evaluation Based on Cognitive Structuring of Episodic Knowledge," in Advances in Consumer Research, Vol. 9, Andrew A. Mitchell, ed., Provo, UT: Association for Consumer Research, 136143.

Sujan, Mita (1985), "Consumer Knowledge: Effects of Evaluation Strategies Mediating Consumer Judgments," Journal of Consumer Research, 12(1), 31-45.

Thompson, Debora Viana and Rebecca W. Hamilton (2006), "The Effects of Information Processing Mode on Consumers' Responses 
to Comparative Advertising," Journal of Consumer Research, 32(4), 530-540.

Tybout, Alice M., Brian Sternthal, Prashant Malaviya, Geogios A. Bakamitsos, and Sebum Park (2005), "Information Accessibility as a Moderator of Judgments: The Role of Content vs. Retrieval Ease," Journal of Consumer Research, 32(1), 76-85.

Unnava, H. Rao and Robert E. Burnkrant (1991), “An Imagery-Processing View of the Role of Pictures in Print Advertisements," Journal of Marketing Research, 28(2), 226-231.

Walker, Beth and Jerry C. Olson (1997), "The Activated Self in Consumer Behavior: A Cognitive Structure Perspective," Research in Consumer Behavior, 8(2), 135-171.

Wyer, Robert S., Iris W. Hung, and Yuwei Jiang (2008), "Visual and Verbal Processing Strategies in Comprehension and Judgment," Journal of Consumer Psychology, 18(4),
244-257.

Yoo, Jun Sang and Hwan Woong Song (2010), "Effect of Mental Simulation on Consumer Response to Innovative New Product," Korea Journal of Marketing, 25 (1), 25-47. Zhao, Min, Darren W. Dahl, and Steve Hoeffler (2014), "Optimal Visualization Aids and Temporal Framing for New Products," Journal of Consumer Research, 41(4), 1137-1151.

Zhao, Min, Steve Hoeffler, and Darren W. Dahl (2009), “The Role of Imagination-Focused Visualization on New Product Evaluation," Journal of Marketing Research, 46(1), 46-55.

Zhao, Min, Steve Hoeffler, and Darren W. Dahl (2012), "Imagination Difficulty and New Product Evaluation," Journal of Product Innovation Management, 29(S1), 76-90. 


\section{$\langle$ APPENDIX〉}

Appendix 1. Visual Description of Innovation Newness Level

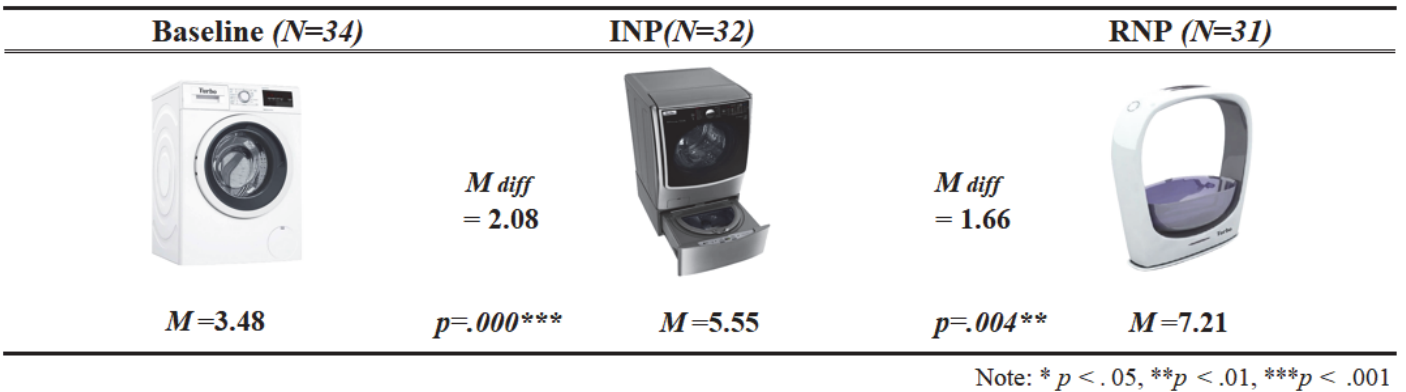

Appendix 2. Stimuli Used in Study 1: Ads with Visual and Verbal Description

\section{$\underline{\text { RNP } x \text { Imagery ad }}$}

\section{New Turbo}

The World's First Waterless and Detergent-Free Washing Machine

You just put your clothes into the Turbo. And you see the dazzling dance of air and light. The fascinating collaboration of air jet stream, ionizing filter, and ultraviolet-C light is a master piece of an art of laundry without using water and detergent.

You feel the angel's touch after Turbo's magical washing

You can rely on the smart Turbo. Just ask Turbo to do a laundry as you wish via your smart phone.

The nature will thank Turbo to its love for the water, the soil, and the sky. Only Turbo can do wash clothes without using water and chemicals.

You will be proud of yourself doing laundry in the most eco-friendly way. Give yourself the present for the future!

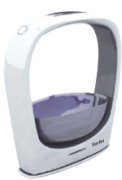

\section{$\underline{\text { INP x Imagery ad }}$}

\section{New Turbo}

Double Washer with Efficient EcoBubble System

You just put your clothes into the Turbo. And you see the dazzling magic of bubble fairy. The EcoBubble system dissolves the detergent thoroughly, and penetrates clothes more quickly with its rich and soapy foam.

You feel the angel's touch after Turbo's magical washing

You can wash two loads at once with top washer for a large load of laundry, and with pedestal washer for a small load of laundry.

You can rely on the smart Turbo.

Just ask Turbo to do a laundry as you wish via your smart phone.

The nature will thank Turbo to its love for the water, the soil, and the sky. Turbo saves water and detergent by $20 \%$.

You will be proud of yourself doing laundry in an eco-friendly way. Give yourself the present for the future!

\section{$\underline{\text { RNP } x \text { Analytical ad }}$}

$$
\text { New Turbo }
$$

The World's First Waterless and Detergent-Free Washing Machine

$$
\text { Features of New Turbo }
$$

\begin{tabular}{|c|c|c|c|}
\hline Features & Effects & Water Consumption & Detergent Consumption \\
\hline Intelligent air jets & Neutralize dirt and grease & \multirow{4}{*}{ No Use } & \multirow{4}{*}{ 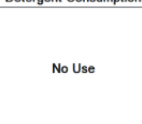 } \\
\hline Electrostatic ionizing filter & Nano-coat the fabricrics & & \\
\hline Ultrviolet-C light & Kill harmful bacteria and viruses & & \\
\hline Wi-Fi technology & $\begin{array}{l}\text { Preset and remote control } \\
\text { the instructions of laundry } \\
\text { via smart phones }\end{array}$ & & \\
\hline
\end{tabular}

The air jets release highly pressurized air currents. The Ionized air currents neutralize dirt and grease, and nano-coat the fabrics. The ultraviolet-C light kills bacteria and viruses.

Wi-Fi technology integrated. Preset the instructions of the laundry course and remote control it via your smart phone.

The AirWash $\circledast$ system is designed only for Turbo (not available with any other existing machines).

No water or chemicals are necessary to run this washing system. Give yourself the present for the future

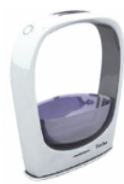

\section{$\underline{\text { INP } \mathrm{x} \text { Analytical ad }}$}

New Turbo

Double Washer with Efficient EcoBubble System

\begin{tabular}{|c|c|c|c|}
\hline Features & Effects & Water Consumption & Detergent Consumption \\
\hline Special bubble generator & $\begin{array}{l}\text { Cleans more efficiently than water- } \\
\text { dissolved detergent }\end{array}$ & \multirow{3}{*}{$\begin{array}{l}\text { Reduce water } \\
\text { by } 20 \%\end{array}$} & \multirow{3}{*}{$\begin{array}{l}\text { Reduce detergent } \\
\text { by } 20 \%\end{array}$} \\
\hline Double washer system & $\begin{array}{l}\text { Top washer for large load of laundry } \\
\text { Pedestal washer for small load of laundry }\end{array}$ & & \\
\hline Wi-Fi technology & $\begin{array}{l}\text { Preset the instructions of laundry } \\
\text { via smart phones }\end{array}$ & & \\
\hline
\end{tabular}

Features of New Turbo

The special bubble generator penetrate clothes more quickly and cleans more efficiently than water-dissolved detergent.

Double washer system. Top washer for a large load of laundry and a pedestal washer below for smaller loads of laundry.

Wi-Fi integrated technology. Preset the instructions of the laundry course and remote control it via your smart phone.

The EcoBubble system is designed only for Turbo (not available with any other existing machines for now).

Water and detergent consumption reduced by $\mathbf{2 0} \%$. Give yourself the present for the future!

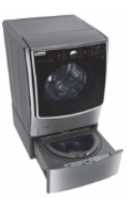




\section{RNP x Imagery ad}

New Allegre Flying Car

The World's First Hydrogen-Powered Flying Car You enter the curve, feel the grip of the seat and enjoy the warmth of morning sunray

Want a futuristic vehicle with an unparalleled luxury and performance?

With seating capacity of four and comfortable ingress and egress, the Allegre is a fascinating choice.

The Allegre flying car looks like a big drone crossed with a luxury suv. Without range anxiety, the Allegre flying car is capable of a car mode on the road and a flight mode in the sky.

You watch the road and the sky unfold. Of course, plenty of delights await inside. You will drive in supreme comfort, and the Allegre flying car certainly seems to offer the essential ingredients to do so.

The seats offer all manners of electrical adjustments, and there are massage functions for driver and passengers that helps to crank up the luxury, no matter how long your journey may be.

Smile and listen to the premium sound system (200 watts and 10 speakers) designed to simply thrill the first time you get in. And every time.

The Allegre flying car is an eco-friendly vehicle, as hydrogen developed for this flying car is produced using renewable energy. You sit back and enjoy the five year unlimited warranty at no additional cost. From the moment you drive Allegre, the car begins to work its magic. It is a spell that's hard to break. Let others dream of magnificent luxury and efficiency. Allegre dares to make it real!

\section{$\underline{\text { INP } x \text { Imagery ad }}$}

New Allegre Flying Car

The World's First Hydrogen-Powered Flying Car

You enter the curve, feel the grip of the seat and enjoy the warmth of morning sunray through a glass of sunroof with a menu of sunshade functions in the standard model.

Want a futuristic vehicle with an unparalleled luxury and performance? With seating capacity of four and comfortable ingress and egress, the Allegre is a fascinating choice.

The Allegre flying car looks like a big drone crossed with a luxury suv. Without range anxiety, the Allegre flying car is capable of a car mode on the road and a flight mode in the sky.

You watch the road and the sky unfold. Of course, plenty of delights await inside. You will drive in supreme comfort, and the Allegre flying car certainly seems to offer the essential ingredients to do so.

The seats offer all manners of electrical adjustments, and there are massage functions for driver and passengers that helps to crank up the luxury, no matter how long your journey may be.

Smile and listen to the premium sound system (200 watts and 10 speakers) designed to simply thrill the first time you get in. And every time.

The Allegre flying car is an eco-friendly vehicle, as hydrogen developed for this flying car is produced using renewable energy. You sit back and enjoy the five year unlimited warranty at no additional cost.

From the moment you drive Allegre, the car begins to work its magic. It is a spell that's hard to break. Let others dream of magnificent luxury and efficiency. Allegre dares to make it real!

\section{$\underline{\text { RNP x Analytical ad }}$}

New Allegre Flying Car

The World's First Hydrogen-Powered Flying Car

Features of the new Allegre Flying Car
\begin{tabular}{|c|c|c|c|c|c|}
\hline $\begin{array}{c}\text { Glass } \\
\text { Sunroof }\end{array}$ & $\begin{array}{c}\text { Driving } \\
\text { Mode }\end{array}$ & $\begin{array}{c}\text { Seating Capacity } \\
\text { and Comforts }\end{array}$ & $\begin{array}{c}\text { Sound } \\
\text { System }\end{array}$ & $\begin{array}{c}\text { Fuel } \\
\text { Type }\end{array}$ & $\begin{array}{c}\text { Unlimited } \\
\text { Watrranty }\end{array}$ \\
\hline Yes & $\begin{array}{c}\text { Car mode } 1 \\
\text { Flight mode }\end{array}$ & $\begin{array}{c}4 \text { people I } \\
\text { Electrical adjustments \& } \\
\text { Massage functions }\end{array}$ & $\begin{array}{c}200 \text { watts } \\
-10 \text { speakers }\end{array}$ & Hydrogen-powered & 5 years \\
\hline
\end{tabular}

Glass sunroof with a menu of sunshade functions in the standard model. Car mode on the road and Flight mode in the sky.

Seating capacity of $\mathbf{4}$ people. Luxury sitting comforts offering all manners of
the electric adjustments and massage functions for driver and passengers. A premium sound system (200 watts and 10 speakers) designed to simply thrill the first time you get in. And every time.

Eco-friendly vehicle powered by hydrogen fuel cell.

Let others dream of magnificent luxury and efficiency. Allergre dares to make it real!

\section{INP x Analytical ad}

New Allegre Flying Car

The World's First Hydrogen-Powered Flying Car

Features of the new Allegre Flying Car
\begin{tabular}{|c|c|c|c|c|c|}
\hline $\begin{array}{c}\text { Glass } \\
\text { Sunroof }\end{array}$ & $\begin{array}{c}\text { Driving } \\
\text { Mode }\end{array}$ & $\begin{array}{c}\text { Seating Capacity } \\
\text { and Comforts }\end{array}$ & $\begin{array}{c}\text { Sound } \\
\text { Systern }\end{array}$ & $\begin{array}{c}\text { Fuel } \\
\text { Type }\end{array}$ & $\begin{array}{c}\text { Unlimited } \\
\text { Watrranty }\end{array}$ \\
\hline Yes & $\begin{array}{c}\text { Car mode I } \\
\text { Flight mode }\end{array}$ & $\begin{array}{c}\text { 4 people I } \\
\text { Electrical adjustments \& } \\
\text { Massage functions }\end{array}$ & $\begin{array}{c}200 \text { watts } \\
-10 \text { speakers }\end{array}$ & Hydrogen-powered & $\mathbf{5}$ years \\
\hline
\end{tabular}

Glass sunroof with a menu of sunshade functions in the standard model. Car mode on the road and Flight mode in the sky.

Seating capacity of $\mathbf{4}$ people. Luxury sitting comforts offering all manners the electric adjustments and massage functions for driver and passengers. A premium sound system (200 watts and 10 speakers) designed to simply thrill the first time you get in. And every time.

Eco-friendly vehicle powered by hydrogen fuel cell.
Five-year unlimited warranty at no additional cost. Let others dream of magnificent luxury and efficiency. 